\title{
Miten sivistyksestä puhutaan
}

\author{
$y$ \\ Sivistys on niin suuri asia, että siitä ei tarvitse huutaa. \\ Sivistys on sanoissa, teoissa ja vaikutuksissa, joita \\ tekomme jättävät.
}

SIVISTYS ON KORKEA tavoite ja ylevä tosiasia. Meillä ei ole mitään syytä tinkiä sivistyksen arvosta ja sisällöstä. Mutta tästä ei seuraa mitään tiettyä tyylin ja ilmaisukeinon suhteen.

Sovellan sivistyksen retoriikkaan eli tapaan, jolla siitä puhutaan, väljästi klassista eetos, paatos ja logos -kolmijakoa.'Eetos' on tekstin, tai puheen, tarkoitus, se mihin pyritään ja miksi teksti on olemassa.'Paatos' on se tapa, eli tyyli, jolla teksti toteuttaa tarkoitustaan, ja 'logos' tekstin asiasisältö.

'Sivistys' puolestaan kuuluu ryhmään, jota nimitän koviksi tosiasioiksi. Se on asiallisesti hyvin pitkälle samaa kuin ihmisyys eli inhimillisyys, ja 'inhimillisyys on käsitteenä samantyyppinen kuin 'sivistys'. Kumpikin käsite ylittää totutun arvojen ja faktojen kahtiajaon, koska ne itse aina ja välttämättä ovat molempia, yhtä aikaa. Kovien tosiasioiden ydintä ovat sellaiset perusulottuvuudet kuin hyvyys, totuus ja kauneus. Sivistyksestä ei oikein puhua ilman, että taustalla on tuon mainitun kolminaisuuden luonne kovana tosiasiana.

Sivistys ei ole asia, jota märittelemme ulkopuolelta ja ahdamme lokeroon, vaan sivistys on se, mitä me olemme ja elämme.

Ja koska ihmisellä on sellainen asia kuin sivistys, hänellä on käytössään sellainen työväline kuin määrittely. Sivistykseen kuuluu se, että osaa arvioida määrittelemisen tapaisten työkalujen käyttökelpoisuutta ja tarpeellisuutta.

Sivistys on siten yhtä aikaa arvo ja tosiseikka, fakta. Jos se olisi vain arvo, se olisi kaunis juhlapuheiden ihanne, jota tavoitellaan mutta joka ei oikein toteudu. Jos se olisi vain tosiseikka, se olisi yksi asia muiden joukossa, tai sitten se lavenisi liikaakin niin, että kaikki olisi sivistystä. Niinhän se on inhimillisyydessäkin: yhtäältä kaikki on inhimillistä, toisaalta inhimillisyys on jotain erityistä, jota pitää edistää, vaatia ja kannattaa.

\section{SIVISTYS ON VAATIMUS JA TAVOITE}

Mitä se on, kun jokin on yhtä aikaa arvo ja tosiseikka? Se on jotain kolmatta. Sivistys on arvon ja tosiseikan lisäksi vaatimus ja tavoite. Sivistyksen pitää olla, ja sivistykseen me pyrimme. Se on myös on koko ajan totta, toteutunutta ja olemassa olevaa.

Sivistys on siten suuntautumista - näköala ja vaatimus. Mutta samalla se on näkökulma, josta tarkastelemme olemassa olevaa. Se on tapa, jolla olemme olemassa.

Sivistyksen luonne määrittelee tapaa, jolla siitä puhumme. Eetoksen, paatoksen ja logoksen tulee 


\section{Sivistys ON SIT $\ddot{A}$,}

\section{MIT ̈̈ OLEMME JA ELÄMME.}

olla tasapainossa keskenään, ja kenties sivistyksessä tasapaino on helppokin löytää. Ne ovat ilman muuta lähellä toisiaan.

Sivistyksen logos, asiasisältö, sisältää tavoitteen ja pyrkimyksen. Ei ole sivistystä joka vain on, mitattavissa, punnittavissa ja arvioitavissa, vaan sivistys on se, joka arvioi ja jonka pitää arvioida. Sivistyksen logos sisältää tavoitteen: meidän on puhuttava sivistyksestä, edistettävä sitä, sitouduttava siihen, elettävä sitä todeksi.

Mutta sittenkin eetos, paatos ja logos ovat myös erillisiä. Sivistyksen paatos voi olla vaikka minkälaista, ja sen pitääkin olla.

\section{SIVISTYKSEEN KUULUU ARMO}

Sivistyksen luonne ylevänä tosiseikkana ja korkeana arvona ei tarkoita sitä, että siitä pitäisi puhua ja sitä pitäisi edistää vain jossain korkeassa tyylilajissa, korkealla paatoksella. Päinvastoin sivistykseenkin sopii se, että voidaan myös puhua tekstiä vastaan. Jos puhum- me todella suuresta asiasta ja meillä on paljon sanottavaa, voimme sanoa sen pienesti ja vaatimattomasti. Jos on todella varma asiastaan ja sanoistaan, niitä ei tarvitse korostaa ja alleviivata. Päinvastoin, suuren ja tärkeän asian voi sanoa pienellä, vaatimattomasti, ohimennen livauttaen.

Sivistys on inhimillisyyttä, ja inhimillisyyteen kuuluvat tunnetusti vajavaisuus ja epätäydellisyys. Silloin siihen kuuluu armo, armollisuus itseäkin kohtaan. Voimme puhua sivistyksestä vaikka millä tavoin ja toimia sen hyväksi vaikka millä tavoin, se on niin suuri asia että siihen mahtuu monenlaista. Sivistys on ennen muuta pieniä sanoja ja pieniä tekoja, mutta toisinaan ja tarvittaessa suuriakin. Sivistyksen kanssa ei tarvitse olla liian mahtipontinen.

Sivistys on sanoissa, joita nyt käytämme mutta myös vaikutuksissa, joita jätämme. Niitä ei aina voi tarkoin tietää ja arvioida. Juuri siksi on syytä uskoa sivistykseen.

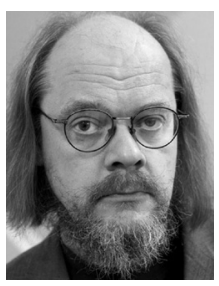

EERO OJANEN

FT, filosofi, kirjailija 